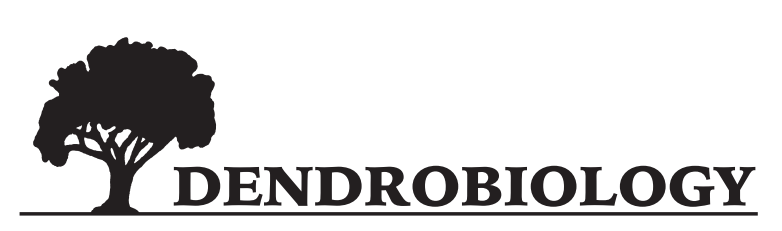

2014, vol. 71, 73-81

http://dx.doi.org/10.12657/denbio.071.007

\author{
Marta Aleksandrowicz-Trzcińska, Stanisław Drozdowski, \\ Bogdan Brzeziecki, Paulina Rutkowska, Barbara Jabłońska
}

\title{
Effects of different methods of site preparation on natural regeneration of Pinus sylvestris in Eastern Poland
}

Received: 27 February 2013; Accepted 20 June 2013

\begin{abstract}
Mechanical site preparation (MSP) is commonly used to enable forest regeneration of clear-cuts. Less intense methods may be more suitable from an environmental point of view, but such a method can result in the lack of natural regeneration. We compare the influence of three MSP methods on natural regeneration of Scots pine. The methods differ in their degree of soil disturbance. The effects of MSP by forest plough (FP), active plough (AP), and forest cutter (FC) on density, quality, and biometric parameters of one-year old seedlings were determined. The highest density of seedlings was obtained in the FP treatment $\left(188,000\right.$ seedlings ha $\left.{ }^{-1}\right)$. The seedling density was significantly lower in the AP method (121,000 seedlings ha ${ }^{-1}$ ), and in the FC variant $\left(36,000\right.$ seedlings $\left.\mathrm{ha}^{-1}\right)$. The best quality seedlings were found in the FC variant, and the worst - in the FP treatment. Most biometric parameters of seedlings did not differ by MSP method, except for the root length and root:shoot ratio. By the end of growing season, in the FP treatment, 1-year old seedlings formed a top bud more than twice as often as the seedlings from the AP and FC treatments. The FP method led to the best Scots pine natural regeneration. The results obtained in the FC variant were not as good as in the FP method, though they were still acceptable from the silvicultural point of view. The FC method was the least intensive method of site preparation, yet it is considered the most appropriate from the environmental (soil protection) point of view.
\end{abstract}

Additional key words: Scots pine, seedling density, seedling growth, seedling quality, soil scarification

Addresses: M. Aleksandrowicz-Trzcińska, Department of Forest Protection and Ecology, Faculty of Forestry, Warsaw University of Life Sciences, 159 Nowoursynowska St., 02-776 Warsaw, Poland, e-mail: marta_aleksandrowicz_trzcinska@sggw.pl

S. Drozdowski, B. Brzeziecki, P. Rutkowska, B. Jabłońska, Department of Silviculture, Faculty of Forestry, Warsaw University of Life Sciences, 159 Nowoursynowska St., 02-776 Warsaw, Poland

\section{Introduction}

Scots pine (Pinus sylvestris L.) is the main tree species in Poland. It constitutes $59.9 \%$ of the area and $61.9 \%$ of the volume of Polish forests (Raport o stanie lasów 2012). For a long time, clear-cuts followed by planting of 1-year old seedlings have been the principal method used to regenerate Scots pine 
stands in Poland. In recent years, natural pine regeneration has been used more and more often. Natural conditions, such as the dominance of conifer forest sites, and the frequently occurrence of good seed years (Tomczyk 1993) as well as the belief that this regeneration method is better from both an ecological and economical point of view (Mattsson and Li 1993; Tomczyk 1993) make the natural regeneration method more favourable.

One of the most important factors determining the success of natural regeneration of Scots pine are weather conditions (temperature and precipitation) during the period of seed germination and initial growth of seedlings (Oleskog and Sahlén 2000b; Puhlick et al. 2012). Meteorological factors strongly interfere with soil moisture conditions. Success of Scots pine seedling recruitment depends largely on soil surface properties, such as the moisture content and the humus depth (Hille and den Ouden 2004). A litter or humus layer without scarification may have a moisture level that is too low for seeds to germinate. The organic soil layer dries out quickly and its moisture regime is highly variable. In such conditions the seedlings are strongly dependent on frequent and sufficient rainfall until their roots reach the mineral soil (Oleskog and Sahlén 2000a). A thick layer of litter and humus may delay or abort seedling emergence by preventing the contact between seminal root and the mineral soil. Mechanical restrictions to hypocotyl elongation and emergence of cotyledons is also caused by the presence of litter and humus (Caccia and Ballaré 1998; Ibáñez and Schupp 2002). That is why, for natural Scots pine regeneration in Poland and in many other countries, a mechanical site preparation (MSP) is recommended. Soil scarification is necessary to improve recruitment and stimulate early growth of Scots pine and other tree species (Agestam et al. 2003; Hille and den Ouden 2004; Karlsson and Nillsson 2005). First of all, the MSP improves moisture conditions. On moist and wet sites it decreases soil water content and increases soil porosity thus improving soil aeration (MacKenzie et al. 2005). On dry sites, MSP improves the water supply in the root zone because transpiring vegetation is removed (Fleming et al 1994). Moreover bare mineral soil has less variation in water availability than the humus layer (Oleskog and Sahlén 2000a).

The MSP is crucial in order to restrict competition for light, water, and nutrition from other vegetation on the clear-cut areas (Nilsson and Örlander 1999). Ground vegetation may sometimes inhibit seed germination and seedling growth by the allelopathic process (Steijlen et al. 1995; Jäderlund et al. 1998).

Soil scarification increases soil temperature (Nilsson and Örlander 1999; Bedford and Sutton 2000), lowers soil bulk density (MacKenzie et al. 2005), and decreases damage caused by the pine weevil (Hylobius abietis L.) (Petersson and Örlander 2003).

MSP also accelerates litter decomposition, increasing the availability of mineral compounds (Lunmark-Thelin and Johansson 1997; Nilsson and Örlander 1999) thus, increases seedling growth (Karlsson and Örlander 2000; Mattsson and Bergsten 2003; Nordborg and Nilsson 2003).

There are many potential methods of the MSP: Ploughing, disc trenching, mounding, bedding, ripping, scalping, patch scarification, and others. The particular methods differ in degree of their impact on the soil, as measured by the area and depth of the disturbed soil (Bedford and Sutton 2000; Neugebauer 2008). According to many comparative studies, more intensive scarification methods usually result in a higher initial number of seedlings, and better subsequent growth and survival (Prévost 1997; Mattsson and Bergsten 2003; Nordborg and Nilsson 2003).

In Poland, for a long time, the traditional double-mouldboard forest plough (FP) had been the most widespread manner of site preparation on clear-cuts. The FP treatment had been used both in artificial (planting) and natural regeneration. However, the FP method leads to a strong modification of soil structure, covering practically the whole area of a clear-cut. Nowadays in forest management, more environment-friendly solutions are preferred. The less-intense soil preparation methods such as active plough (AP) and the forest cutter (FC) are increasingly used as alternatives to FP. So far, however, little is known about the impact of these methods on the relative performance and basic growth characteristics of the new forest generation. Even less is known about these factors in the case of natural regeneration.

With this study, we aimed to compare the influence of three MSP methods. Each method interferes with the soil environment to a different degree. The methods compared density, quality, and selected biometric parameters of Scots pine regeneration, as estimated by the end of the first growing season after natural seeding. We believed the best results would be obtained in the FP method, followed by the AP variant. We also expected that the FC treatment, as the least intense method, could even result in a lack of success of natural regeneration.

As the expected results should give an answer to the question whether the use of less invasive MSP methods create conditions good enough for obtaining natural regeneration of Scots pine in conditions of eastern Poland, we assume that already 1-yearlong observation period should be sufficient to assess usefulness of MSP methods regardless regeneration development in subsequent years (seedlings death, recruitment new plants). 


\section{Methods}

\section{Study site}

The study was carried out in the Ostrów Mazowiecka Forest District $\left(52^{\circ} 80^{\prime} \mathrm{N}, 21^{\circ} 90^{\prime} \mathrm{E}\right.$; WGS $84)$, located $70 \mathrm{~km}$ north-east of Warsaw, Poland. The annual mean temperature in the study area is $7.5^{\circ} \mathrm{C}$. The warmest month is July $\left(17.9^{\circ} \mathrm{C}\right)$ and the coldest is January $\left(-3.2^{\circ} \mathrm{C}\right)$. The vegetation period (mean daily air temperature above $+5^{\circ} \mathrm{C}$ ) begins in mid-April and lasts, on average, 210 days. The long-term mean annual precipitation is $580 \mathrm{~mm}$, of which ca. $70 \%$ falls during the vegetation period (Koźmiński and Michalska 1999).

Soil at the study site is classified as Haplic Podzols formed from glaciofluvial sand and humus belonging to a mor type. The depth of humus layer is $5-7 \mathrm{~cm}$ (L 7(5) $-3 \mathrm{~cm}, \mathrm{~F} 3-1 \mathrm{~cm}, \mathrm{H} 1-0 \mathrm{~cm}$ ). Before clear-cutting, the area was stocked with a 120 -year-old Scots pine (P. sylvestris) stand (stand volume ca. $400 \mathrm{~m}^{3} / \mathrm{ha}$; stand density appr. 300 stems/ha; average tree height ca. $26 \mathrm{~m}$ ). The plant community was classified as Peucedano-Pinetum typicum. The underbrush consisted of Sorbus aucuparia, Picea abies, Juniperus communis and Quercus petraea. Ground vegetation was made up of Vaccinium myrtillus, Hylocomium splendens, Convallaria majalis, Solidago virgaurea, Vaccinium vitis-idea and Pleurosium schreberi (Management Plan 2005). The height of ground vegetation was differentiated: $\mathrm{ca} .10 \mathrm{~cm}$ in patches dominated by mosses, $15-25 \mathrm{~cm}$ in Vaccinium and Convallaria patches and up to $80 \mathrm{~cm}$ in S. virgaurea patches). The stand was removed in winter and spring 2006.

\section{Mechanical site preparation methods}

For the purpose of this study, four experimental clear-cuts, $420 \mathrm{~m}$ long and 55-60 m wide, were established. This is a typical size for a clear-cut in Poland. The area of each clear-cut was divided into three 140 $\mathrm{m}$ long parts corresponding to the MSP method.

In autumn 2006, the MSP was performed using an $\mathrm{LPz} 75$ double-mouldboard forest plough, a single-mouldboard U-162 active plough, and a FAOFAR FV 4088 forest cutter.

Rectangular furrows were created with a FP. Litter and humus were removed to expose mineral soil. The upper layer of the cut-out, formed a ridge consisting of mineral soil. Humus layer, litter, and ground vegetation were located below. The furrows covered ca. $50 \%$ of the clear-cut area. The ridges covered the remaining 50\% (Sutton 1993; Neugebauer 2008).

A rotating mouldboard of the AP gave the furrows a parabolic shape. Mineral soil is only partially exposed and is often mixed with some humus that re- mains or falls down from the rotating mouldboard. Partial mixing of litter, humus and mineral soil takes place on the ridge. In this MSP, ca. $40 \%$ of the clearcut area consisted of furrows, ca. $40 \%$ of ridges, and the remaining $20 \%$ of untreated soil (Sutton 1993; Neugebauer 2008).

The FC crushed and mixed ground vegetation, litter, the humus layer, and mineral soil up to $35 \mathrm{~cm}$ in depth - in $40 \mathrm{~cm}$ wide strips $(27 \%$ of the clearcut area). The strips were separated by ca. $110 \mathrm{~cm}$ wide belts of untouched soil. They covered $73 \%$ of the clear-cut area (MacKenzie et al. 2005; Neugebauer 2008).

The distance between the middle of adjacent furrows or strips was $1.5 \mathrm{~m}$, in all the MSP methods.

The natural regeneration of Scots pine started in spring 2007. The adjacent stands acted as the seed source. These stands were located west of the clearcuts, on the east sides were young stands.

\section{Field and laboratory measurements of seedlings}

At the end of September 2007, an assessment of seedling density and quality was carried out. On each clear-cut, 180 sample plots were established; 60 for each MSP method. This means that on four clearcuts, a total of 720 plots were established. The sample plots formed 6 rows running parallel to a longer side of the clear-cut and consisting of 30 sample plots (10 for a given MSP variant). The distance between rows was $9 \mathrm{~m}$ (multiple of a distance between furrows/ strips amounting to $1.5 \mathrm{~m}$ ). The distance between sample plot centres was ca. $14 \mathrm{~m}$. Sample plots (1.5 $\mathrm{m}^{2}, 1 \mathrm{~m} \times 1.5 \mathrm{~m}$ ) covered both treated tracks of soil (furrows and strips) as well as ridges and untreated areas (belts of untouched soil between strips). Within each plot, all seedlings were counted and classified into 3 quality classes: A - strong, healthy, tall and of medium height seedlings with dark green needles; B - less vigorous, tall and of medium height seedlings, slightly weakened with minor mechanical damage, slight symptoms of yellowing of needles tops, slight chlorosis or discoloration as well as low seedlings without symptoms of weakness or damage; $\mathrm{C}$ - seedlings considerably damaged mechanically or with heavy discoloration of needles, dying-off or dead. The average number of seedlings in the plots was use as observation.

In addition, 384 ( 4 clear-cuts $\times 3$ MSP $\times 2$ microsites $\times 16$ seedlings) one-year-old Scots pine seedlings (shoots and roots together with soil) were collected for biometric analysis. They were taken from the furrows and strips (microsite 1) as well as from ridges and areas of untouched soil located between strips (microsite 2). Seedlings were collected randomly 
from the middle part of the plot in each variant: one seedling per every second furrow/strip and ridge/out of strip, starting from the west side. Samples were put into labelled plastic bags.

For each seedling, the diameter of a root collar and a shoot length were measured. The number of lateral shoots and the presence of the top bud were also determined. After drying the seedlings at $105^{\circ} \mathrm{C}$, an above and below ground dry mass and a root:shoot dry weight ratio were determined. The Böhm's (1985) crossing method was used to determine the total length of the root system. The method is based on the random location of the roots on a net of squares of a given length, and of counting the number of lines they cross. Root length $[\mathrm{L}, \mathrm{cm}]$ was calculated according to the following formula:

$$
\mathrm{L}=11 / 14 \times \mathrm{n} \times \mathrm{a},
$$

where: $\mathrm{n}$ - number of crossings with net of squares, $\mathrm{a}$ - square side length (here $0.5 \mathrm{~cm}$ ).

\section{Statistical analysis}

Before the analyses, the normality of data distribution in individual treatment areas (Shapiro-Wilk test) and homogeneity of their variance (Levene's test) were tested. Due to differences in the variance and deviance from the normal distribution within samples, the non-parametric Friedman test was used. The post-hoc Wilcoxon singned-rank test was used to detect homogenous groups. Finally, a logistic regression was applied to analyse the influence of the MSP method on biometric seedling parameters and the formation of top bud. All calculations and investigations were carried out with Statistica 9.0 (StatSoft, Inc.) software.
The sample plots were divided into classes of seedling density in relation to number of seedlings per plot $\left(1.5 \mathrm{~m}^{2}\right)$. The seedling density classes were: 0 - null - "zero plots", 1 - 1-9 seedlings; 2 - 10-19 seedlings; ... $7-60-69 ; 8>70$. Plot frequency in the density classes was calculated within each MSP treatment (in \%).

\section{Results}

The overall density of seedlings differed significantly between treatments (Friedman test, P < 0.001 ). The highest seedlings density of $18.8 / \mathrm{m}^{2}$ was obtained with the FP treatment. For the AP and FC treatments, the average seedling density was $12.1 / \mathrm{m}^{2}$ and $3.6 / \mathrm{m}^{2}$, respectively (Fig. 1).

Within a given MSP, the density of seedlings was not uniform. In the FC treated area, the sample plots with no seedlings amounted to $7.1 \%$, while most

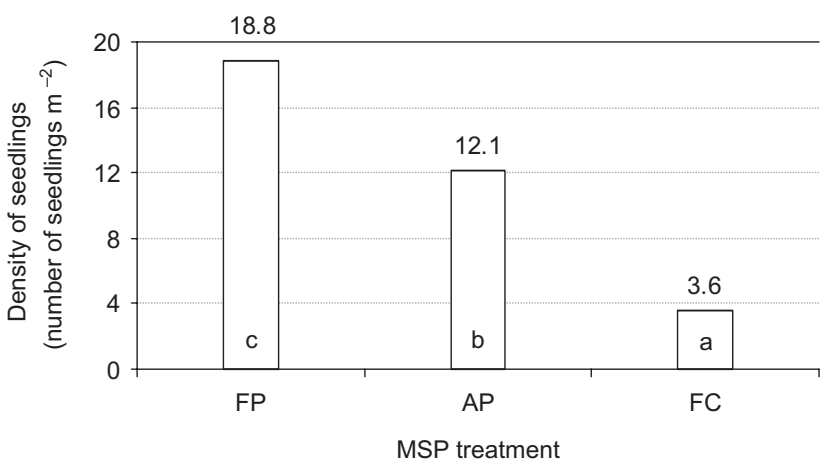

Fig. 1. The average density (seedling $\mathrm{m}^{-2}$ ) of Scots pine seedlings in the three variants of MSP: FP - forest plough, AP - active plough, and FC - forest cutter. Different letters indicate significant difference in the Friedman test, $\mathrm{P} \leq 0.001$

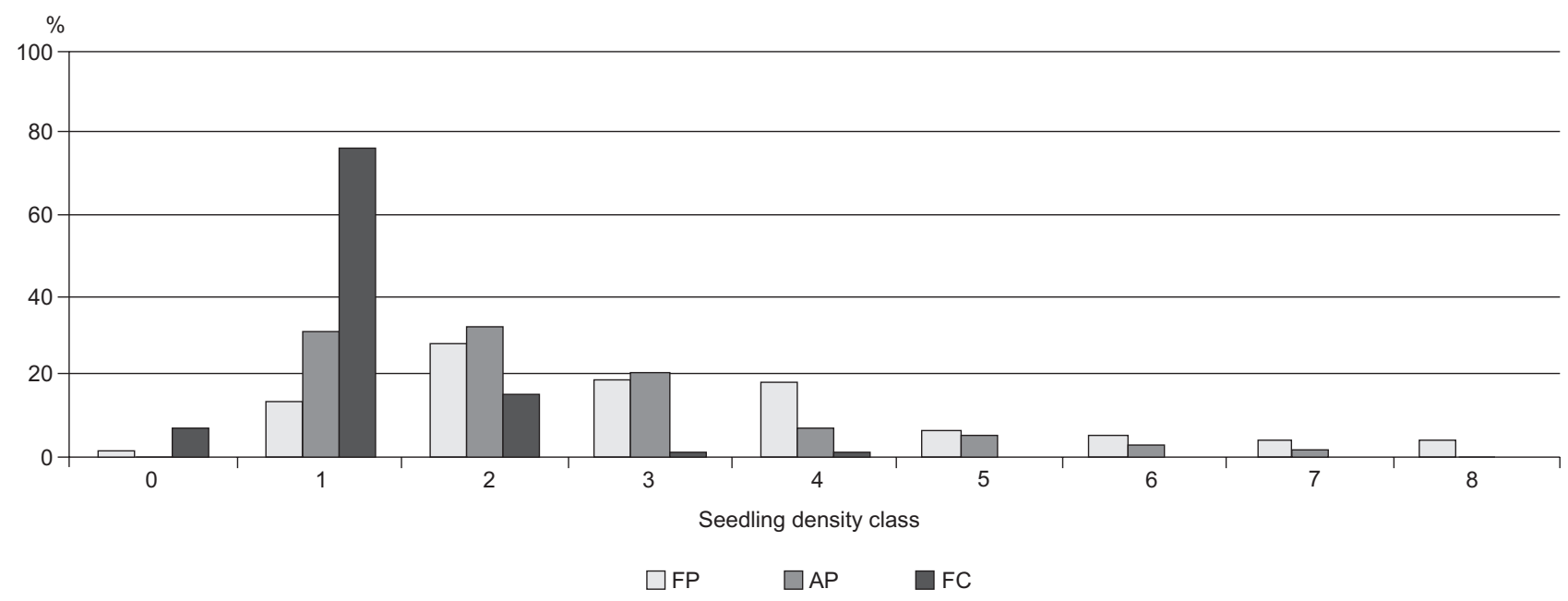

Fig. 2. Sample plots frequency (\%) of seedling density classes in relation to the MSP methods: FP - forest plough, AP active plough, and FC - forest cutter. Seedling density classes: 0 - "zero plots", 1 - 1-9 seedlings; 2 - 10-19 seedlings; ... 7 - 60-69; $8>70 ;$ no./1.5 $\mathrm{m}^{2}$ 


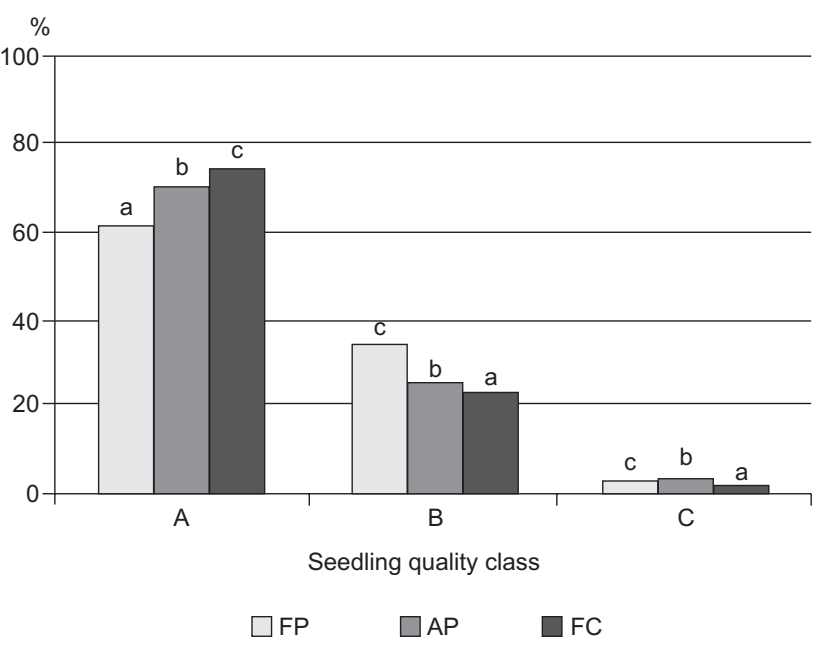

Fig. 3. A percentage share of seedling quality classes in relation to the MSP methods: FP - forest plough, AP - active plough, and FC - forest cutter. Seedlings quality classes are: A - strong and healthy, B - slightly weakened or damaged, C - strongly weakened or dying. Different letters indicate significant difference in the Friedman test, $\mathrm{P} \leq 0.05$

sample plots $(80 \%)$ contained between 1 to 9 seedlings. In the two other MSP methods; FP and AP, almost all sample plots contained at least 1 pine seedling (Fig. 2).

The best quality of seedlings was found on soil prepared with the FC method. This treatment resulted in the highest share of best-quality pines (A class) $-74.4 \%$. The share of the class $C$ seedlings was only $2 \%$. The worst results in this respect were obtained with the FP method (Fig. 3).

After the first year of growth, on the clear-cuts prepared with the various MSP tools (FP, AP, FC), pine seedlings differed in their root system length, root:shoot dry weight ratio, and number of seedlings with top bud established. The seedlings in the AP variant were characterised by significantly longer roots. The seedlings in the FC method had the smallest root:- shoot ratio (Table 1 and 2). In turn, pines growing on soil prepared with the FP method had established top buds (during the investigation, i.e. by the end of September) twice as often as trees in the other MSP (FP - 29.7\%; AP - 13.3\%; FC - 14.8\%).

By means of logistic regression, we found that the number of seedlings with their top bud formed, differed significantly between the MSP methods $(\mathrm{P}=$ 0.0024; total loss $=183.61 ; \chi^{2}=9.1858 ; \mathrm{N}=384$ ). However, no significant relationships were found between number of seedlings with top bud and their biometric features (shoot length, $\mathrm{P}=0.1585$; root collar diameter, $\mathrm{P}=0.6835$; above ground dry mass, $\mathrm{P}=0.3028$; root length, $\mathrm{P}=0.1082$; root dry mass, $\mathrm{P}$ $=0.8128$; root branching index, $\mathrm{P}=0.5518$ ) .

For the significant influence of MSP, on the number of seedlings with top-bud formed in their first year of life, we determined the odds ratio of the top bud formation. For the FP variant, the odds ratio was 2.76 fold higher than in the AP method, and 2.42 fold higher than in the FC method.

\section{Discussion}

Our research shows that one-year old Scots pine seedlings can significantly differ with respect to general density, quality, and key biometric variables, depending on the MSP method used.

The most important parameter - the seedling density - was very high in the FP method (188,000 seedlings $\left.\mathrm{ha}^{-1}\right)$, rather high in the AP method (121,000 seedlings $\mathrm{ha}^{-1}$ ), and (relatively) low in the FC treatment $\left(36,000\right.$ seedlings $\left.\mathrm{ha}^{-1}\right)$. It appears that with the less intensive soil preparation method, the initial number of seedlings is smaller. Most probably, the differences in seedling density were caused by different seedbed moisture conditions in each MSP variant. The FP method exposes the mineral soil on almost the whole clear-cut area. For various tree species, bare mineral soil has been demonstrated to be an optimal seed-

Table 1. Growth parameters (mean and standard error in parentheses) of aboveground part of Scots pine seedlings from natural regeneration in relation to site preparation method

\begin{tabular}{lcccc}
\hline \multicolumn{1}{c}{ Treatment } & Shoot length $(\mathrm{cm})$ & Root collar diameter $(\mathrm{mm})$ & Aboveground dry mass $(\mathrm{g})$ & Number of lateral shoots (pcs) \\
\hline Forest plough (FP) & $6.25(0.14) \mathrm{a}$ & $1.59(0.04) \mathrm{a}$ & $0.424(0.03) \mathrm{a}$ & $2.0(0.12) \mathrm{a}$ \\
Active plough (AP) & $6.41(0.14) \mathrm{a}$ & $1.50(0.03) \mathrm{a}$ & $0.375(0.02) \mathrm{a}$ & $2.0(0.12) \mathrm{a}$ \\
Forest cutter (FC) & $6.48(0.13) \mathrm{a}$ & $1.58(0.03) \mathrm{a}$ & $0.425(0.02) \mathrm{a}$ & $2.3(0.15) \mathrm{a}$ \\
\hline
\end{tabular}

The same letter indicates no significant difference in the Friedman test, $\mathrm{P} \leq 0.05$.

Table 2. Growth parameters (mean and standard error in parentheses) of root and root-shoot ratio of Scots pine seedlings from natural regeneration in relation to site preparation method

\begin{tabular}{lccc}
\hline \multicolumn{1}{c}{ Treatment } & Root length $(\mathrm{cm})$ & Root dry mass $(\mathrm{g})$ & $\begin{array}{c}\text { Root branching index } \\
(\mathrm{pcs} / \mathrm{cm})\end{array}$ \\
\hline Forest plough (FP) & $70.0(3.1) \mathrm{a}$ & $0.065(0.003) \mathrm{a}$ & $5.1(0.15) \mathrm{a}$ \\
Active plough (AP) & $80.8(3.4) \mathrm{b}$ & $0.061(0.002) \mathrm{a}$ & $4.9(0.11) \mathrm{a}$ \\
Forest cutter (FC) & $70.5(3.3) \mathrm{a}$ & $0.061(0.003) \mathrm{a}$ & $5.1(0.13) \mathrm{a}$ \\
\hline
\end{tabular}

Different letters indicate significant difference in the Friedman test, $\mathrm{P} \leq 0.05$. 
bed (Prévost 1997; Agestam et al. 2003). The degree of seed-soil contact and the capillary water transport to the soil surface were found to be higher in mineral soil than in other substrates such as humus, organic and intact soil (Oleskog and Sahlén 2000a, 2000b; de Chantal et al. 2004). Mixing of ground vegetation, litter, humus layer and mineral soil, which takes place on the AP ridge and in the FC strip, and untreated soil on FC belt, under clear-cut conditions (low air humidity, high solar radiation and ventilation) may create seedbed too dry for seed germination (MacKenzie et al. 2005). The water supply from such substrate does not compensate for the water evaporation lost from the soil surface and seeds, especially during the daytime (Oleskog et al. 2000). Soil preparation by means of the AP and FC tools causes excessive soil surface desiccation. This is true even if deeper soil strata can be characterized by a better water supply (Ludmark-Thelin and Johansson 1997), so conditions for seed germination are here worse than in mineral soil. The study by Béland et al. (2000), also indicated that germination was significantly better on mineral soil than on mineral soil mixed with humus.

Mineral soil is the coldest seedbed, but in the clear-cut conditions, the minimum temperature is higher on this seedbed substrate than on intact soil or humus layer or organic material. Gradient of soil and air temperature may induce the movement of water through the soil, thus water drops form on the surface of mineral soil. Such a process meant that moisture content in seeds was higher when in the mineral soil then in other substrates (Oleskog and Sahlén 2000a). This phenomenon causes better seedlings emergence in the FP method.

The density of seedling is highest at sites with high mean annual precipitation (Puhlick et al. 2012). The mean annual precipitation of $580 \mathrm{~mm}$, which occurs in the study area (Koźmiński and Michalska 1999), is considered to be close to the minimum needed to obtain natural Scots pine regeneration in Poland (Tomczyk 1993). The FP method provided the most favourable seedbed substrate moisture conditions. Such conditions, along with a satisfactorily high water retention capacity (de Chantal et al. 2004), and the fact that the substrate water is readily available to the seeds (Oleskog and Sahlén 2000a) resulted in the highest density of seedlings. It can be expected that in regions with a higher precipitation (Puhlick et al. 2012) or in a moist growing season (de Chantal et al. 2003), the density of seedlings on the soil prepared by means of the AP and FC methods could be higher than that obtained in this study. Improvement of moisture conditions of intact soil and mixed ground vegetation, litter, humus layer and mineral soil on ridge or strips (Béland et al. 2000; Oleskog and Sahlén 2000b) due to rain water might provide higher seedling density.
Under favourable conditions, the initial number of Scots pine seedlings originating from natural regeneration can amount to several tens of thousands or even hundreds of thousands per hectare (Béland et al. 2000; Andrzejczyk and Drozdowski 2003). In this study, the initial density of seedlings, particularly in the FC treatment, was rather moderate. However, even in this MSP method, it was about 4 times higher than the initial density of seedlings applied in artificial regeneration (according to Silvicultural Guidelines (2012) between 8000-10,000 1-year old pine seedlings should be planted per $1 \mathrm{ha}$ ). Therefore, even in the FC variant, the seedling density may be considered more than sufficient. In subsequent years, some amount of new seedlings will emerge as a result of additional seed rain from adjacent stands (Béland et al. 2000, Karlsson and Örlander 2000, Karlsson et al. 2002). It is important to note, that quality (vigour) of the seedlings was the highest in the FC method. The FP method was distinguished by the lowest quality of seedlings which may have also been caused by the seedlings' high density.

The similarly low proportion of zero-seedling plots in the FP and AP methods, indicates that these methods of soil scarification produce a more homogeneous ground (Karlsson and Nilson 2005). On the other hand, a higher proportion of zero-seedling plots in the FC treatment suggests that due to the relatively low intensity of the soil treatment, a higher microsite variation of clear-cut area is retained (Pigan 2009). The intact soil covered $73 \%$ of the clear-cut area in the FC treatment. The undisturbed bottom layer consisted of some mosses, mainly P. schreberi and $H$. splendens. The field layer was composed of dwarf shrubs ( $V$. myrillus and V. vitis-idaea) and other plants (Management Plan 2005). This vegetation creates a heterogeneous surface and is known to provide conditions which are generally too dry for germination (Oleskog and Sahlén 2000a). Poor contact between seed and intact soil, especially in places where the bottom layer consists of mosses, might have been the reason for the low germination (Oleskog and Sahlén 2000a). Allelopathy may also inhibit seed germination in intact soil (Steijlen et al. 1995; Jäderlund et al. 1998). Results showing a higher number of plots without seedlings in places where there is intact soil, have also been found in other studies (Karlsson and Örlander 2000; Karlsson et al. 2002). Because of the low share of zero-seedling plots $(7.1 \%)$ a supplementary planting was not needed (Silvicultural Guidelines 2012).

The various MSP tools create different conditions for the development of seedling allometry. After the first growing season, pine seedlings varied in the total length of their root system, and in their root:shoot ratio. Tree seedling root growth is influenced by such physical factors of soil as: temperature, water, me- 
chanical resistance, and aeration (Sayer et al. 2005; Morris et al. 2006). The root growth is positively correlated with soil temperature (Lopushinsky and Max 1990) and negatively with water stress (Sayer et al. 2005). The longest roots which were found in the AP method, may suggest the higher soil temperature in this MSP. Raising and mixing forest floor and mineral soil on the AP ridge, and leaving some humus on the bottom of the AP furrow, creates better thermal conditions than in other MSP methods (MacKenzie et al. 2005). High root growth which occurred in the AP treatment, might also be explained by a lower bulk density, especially on AP ridges as well as better aeration, and low root penetration resistance (Nordborg and Nilsson 2003; MacKenzie et al. 2005).

Shading reduces the root:shoot dry mass ratio (Van Hees and Clerkx 2003). If light availability decreases, light-demanding tree species, like Scots pine, react with a vary steep decrease in the root:shoot ratio (Wagner et al. 2011). The presence of vegetation on belts of untreated soil in the FC variant may be responsible for shading of seedlings. In contrast, soil scarification by means of the FP and AP methods strongly reduces the development of vegetation. Regeneration of vegetation does not start before the second or even the third year after the soil treatment (Nordborg and Nilsson 2003; Löf et al. 2006). Consequently, the root:shoot ratio of seedlings in the FC method is lower in comparison to the FP and AP variants.

Formation of a top buds, their number and size may be indication of vigour of seedlings and their growth conditions (Gavrikov and Sekretenko 1996; Khan et al. 1996; Wennström et al. 2002). In our study, formation of a top bud on the seedlings which were harvested in September, may indirectly point to more favourable conditions for seed germination and seedling growth. Considering this trait, we observed that the best conditions were created with the FP tool.

\section{Conclusions}

The strongest modification of soil environment occurs in the traditional FP method of soil preparation. Exposing large tracts of mineral soil in this MSP treatment appears to secure the best conditions for seed germination and initial growth of seedlings. This finding is confirmed by a high initial density of seedlings and by an early formation of top buds. In comparison to the FP treatment, the AP variant is a less intense method of soil preparation (yet, more intense than the FC variant). Accordingly, the key parameters of natural regeneration established on the soil prepared by the AP method take on intermediate values, both in quantitative and qualitative terms. The FC treatment is the least intensive method, as it involves merely ca. $30 \%$ of the whole cutting area. The quality of seedlings established in this MSP method is the highest. The density of seedlings growing in the FC variant is markedly smaller than in the two other variants however, it clearly exceeds the initial number of seedlings used in artificial regeneration (planting). From the point of view of soil disturbance, the FC method ranks as the least destructive method of site preparation.

The results obtained in this study are preliminary. In the subsequent years, quantitative and qualitative changes in the population of seedlings can occur as a result of emergence of new and mortality of existent seedlings. Nevertheless, it can be concluded that seedbed conditions created by less intense site preparation methods (including least invasive FC method), enable a successful establishment and initial growth of natural regeneration of Scots pine in eastern Poland.

\section{Acknowledgements}

We are grateful to Mr. Piotr Uścian-Szaciłowski, District Forest Manager of the Ostrów Mazowiecka Forest District for his invaluable support and help during the field part of the study. The research was partly financed by the Rector of the Warsaw University of Life Sciences, within grant 504-10-03040016.

\section{References}

Agestam E., Ekö P.M., Nilsson U, Welander N.T. 2003. The effects of shelterwood density and site preparation on natural regeneration of Fagus sylvatica in southern Sweden. Forest Ecology and Management 176: 61-73.

Andrzejczyk T., Drozdowski S. 2003. Rozwój naturalnego odnowienia sosny zwyczajnej na powierzchni przygotowanej pługiem dwuodkładnicowym. Sylwan 5: 28-35.

Bedford L., Sutton R.F. 2000. Site preparation for establishing lodgepole pine in the sub-boreal spruce zone of interior British Columbia: the Bednesti trial, 10-year results. Forest Ecology and Management 126: 227-238.

Béland M., Agestam E., Ekö P.M., Gemmel P., Nilsson U. 2000. Scarification and seedfall affects natural regeneration of Scots pine under two shelterwood densities and clear-cut in southern Sweden. Scandinavian Journal of Forest Research 15: 247-255.

Böhm W. 1985. Metody badania systemów korzeniowych. PWRiL Warszawa, pp 199-202.

Caccia F.D., Ballaré C.L. 1998. Effects of tree cover, understory vegetation, and litter on regeneration of Douglas-fir (Pseudotsuga manziessii) in south- 
western Argentina. Canadian Journal of Forest Research 28: 683-692.

de Chantal M., Leinonen K., Ilvesniemi H., Westman C.J. 2003. Combined effects of site preparation, soil properties, and sowing date on the establishment of Pinus silvestris and Picea abies from seeds. Canadian Journal of Forest Research 33: 931-945.

de Chantal M., Leinonen K., Ilvesniemi H., Westman C.J. 2004. Effects of site preparation on soil properties and on morphology of Pinus silvestris and Picea abies seedlings sown at different dates. New Forests 27:159-173. http://dx.doi. org/10.1023/A:1025042632491

Fleming R.L., Black T.A., Eldridge N.R. 1994. Effects on site preparation on root zone soil water regimes in high-elevation forest clearcuts. Forest Ecology and Management 68:173-188. http://dx. doi.org/10.1016/0378-1127(94)90044-2

Gavrikov V.L., Sekretenko O.P. 1996 Shoot-based three-dimensional model of young Scots pine growth. Ecological Modelling 88: 183-193.

Hille M., den Ouden J. 2004. Improved recruitment and early growth of Scots pine (Pinus sylvestris L.) seedlings after fire and soil scarification. European Journal of Forest Research 123: 213-218.

Ibáñez I., Schupp E.W. 2002. Effects of litter, soil surface conditions, and microhabitat on Cerocarpus ledifolius Nutt. seedling emergence and establishment. Journal of Arid Environments 52: 209-221.

Jäderlund A., Norberg G., Zackrisson O., Dahlberg A., Teketay D., Dolling A., Nilsson M.C. 1998. Control of bilberry vegetation by steam treatment - effects on seeded Scots pine and associated mycorrhizal fungi. Forest Ecology and Management 108: 275-285.

Karlsson C., Örlander G. 2000. Soil scarification shortly before a rich seed fall improves seedling establishment in seed tree stands of Pinus sylvestris. Scandinavian Journal of Forest Research 15: 256-266.

Karlsson M., Nilsson U. 2005. The effects of scarification and shelterwood treatments on naturally regenerated seedlings in southern Sweden. Forest Ecology and Management 205: 183-197.

Karlsson M., Nilsson U., Örlander G. 2002. Natural regeneration in clear-cuts: effects of scarification, slash removal and clear-cut age. Scandinavian Journal of Forest Research 17: 131-138. http:// dx.doi.org/10.1080/028275802753626773

Khan S.R., Rose R., Haase D.L., Sabin T.E. 1996. Soil water stress: Its effects on phenology, physiology, and morphology of containerized Douglas-fir seedlings. New Forests 12: 19-39.

Koźmiński C., Michalska B. 1999. Ćwiczenia z agrometeorologii. Wydawnictwo Naukowe PWN, Warszawa.
Löf M., Rydberg D., Bolte A. 2006. Mounding site preparation for forest restoration: Survival and short term growth response in Quercus robur L. seedlings. Forest Ecology and Management 232: 19-25.

Lopushinsky W., Max T.A. 1990. Effect of soil temperature on root and shoot growth and on budburst timing in conifer seedling transplants. New Forests 4: 107-124. http://dx.doi.org/10.1007/ BF00119004

Lundmark-Thelin A., Johansson M.B. 1997. Influence of mechanical site preparation on decomposition and nutrient dynamics of Norway spruce (Picea abies (L.) Karst.) needle litter and slash needles. Forest Ecology and Management 96: 101-110.

MacKenzie M.D., Schmidt M.G., Bedford L. 2005. Soil microclimate and nitrogen availability 10 years after mechanical site preparation in northern British Columbia. Canadian Journal of Forest Research 35: 1854-1866.

Management Plan 2005. Operat urządzania lasu dla Nadleśnictwa Ostrów Mazowiecka na lata 20052014.

Mattsson L., Li C.-Z. 1993. The non-timber value of northern Swedish Forest - an economic analysis. Scandinavian Journal of Forest Research 8: 426434.

Mattsson S., Bergsten U. 2003. Pinus contorta growth in northern Sweden as affected by soil scarification. New Forests 26: 217-231.

Morris L.A., Ludovici K.H., Torreano S.J., Carter E.A., Lincoln M.C., Will R.E. 2006. An approach for using general soil physical condition - root growth relationships to predict seedling growth response to site preparation tillage in loblolly pine plantations. Forest Ecology and Management 227: 169177.

Neugebauer Z. 2008. Poradnik dla operatorów maszyn leśnych agregowanych na ciągnikach. Dyrekcja Generalna Lasów Państwowych, Warszawa-Bedoń.

Nilsson U., Örlander G. 1999. Vegetation management on grass - dominated clearcuts planted with Norway spruce in southern Sweden. Canadian Journal of Forest Research 29: 1015-1026.

Nordborg F., Nilsson U. 2003. Growth, damage and net nitrogen uptake in Picea abies (L.) Karst. seedlings, effects of site preparation and fertilization. Annals of Forest Science 60: 657-666.

Oleskog G., Sahlén K. 2000a. Effect of seedbed substrate on moisture conditions and germination of Pinus sylvestris (L.) seeds in clear-cut. Scandinavian Journal of Forest Research 15: 225-236.

Oleskog G., Sahlén K. 2000b. Effect of seedbed substrate on moisture conditions and germination of Scots pine (Pinus sylvestris) seeds in a mixed conifer stand. New Forests 20: 119-133. 
Oleskog G., Grip H., Bergsten U., Sahlén K. 2000. Seedling emergence of Pinus sylvestris in characterized seedbed substrates under different moisture conditions. Canadian Journal of Forest Research 30: $1766-1777$.

Petersson M., Örlander G. 2003. Effectiveness of combinations of shelterwood, scarification, and feeding barriers to reduce pine weevil damage. Canadian Journal of Forest Research 33: 64-73.

Pigan I. 2009. Wpływ sposobu przygotowania gleby na stan upraw sosnowych w warunkach siedlisk wilgotnych. Sylwan 153 (11): 745-757.

Prévost M. 1997. Effects of scarification on seedbed coverage and natural regeneration after a group seed-tree cutting in a black spruce (Picea mariana) stand. Forest Ecology and Management 94: 219231.

Puhlick J.J., Laughlin D.C., Moor M.M. 2012. Factors influencing ponderosa pine regeneration in the southwestern USA. Forest Ecology and Management 264: 10-19.

Raport o stanie lasów w Polsce. 2012. Centrum Informacyjne Lasów Państwowych. Warszawa.

Sayer M.A.S., Brissette J.C., Barnett J.P. 2005. Root growth and hydraulic conductivity of southern pine seedlings in response to soil temperature and water availability after planting. New Forests 30: 253-272.

Silvicultural Guidelines 2012. Zasady Hodowli Lasu. DGLP, Ośrodek Rozwojowo-Wdrożeniowy Lasów Państwowych w Bedoniu.

Steijlen I., Nilsson M.-C., Zackrisson O. 1995. Seed regeneration of Scots pine in boreal forest stand dominated by lichen and feather moss. Canadian Journal of Forest Research 25: 713-723.

Sutton R.F. 1993. Mounding site preparation: A revive of European and North American experience. New Forests 7: 151-192.

Tomczyk S. 1993. Odnowienie naturalne. Sosna. Biblioteczka leśniczego z. 29. Wydawnictwo Świat.

Van Hees A.F.M., Clerkx A.P.P.M. 2003. Shading and root-shoot relations in samplings of silver birch, pedunculate oak and beech. Forest Ecology and Management 176: 439-448.

Wagner S., Fischer H., Huth F. 2011. Canopy effects on vegetation caused by harvesting and regeneration treatments. European Journal of Forest Research 130: 17-40.

Wennström U., Bergsten U., Nilsson J.-E. 2002. Effects of seed weight and seed type on early seedling growth of Pinus sylvestris under harsh and optimal conditions. Scandinavian Journal of Forest Research 17: 118-130. 